\title{
The Europe of
}

\section{Regions and Separatism}

\section{Bölgelerin ve Ayrilıkçıllğın Avrupası}

\author{
Emrullah Ataseven* \\ Ağrı İbrahim Çeçen University, Faculty of Economics and Administrative Sciences, Political Science \& Public Administration, \\ Ağrı, Turkey
}

\begin{abstract}
This study focuses on regions and approaches to regionalism in Europe, which has a long history and heritage. It was anticipated that the regions would be represented more strongly at the European level when the European Common Market was completed. Indeed, after joining the European Union, many European countries have guaranteed to govern their regions in accordance with the principles of subsidiarity and subordination. But some autonomous regions, such as Catalonia, emerged with "radical" demands such as independence rather than broad autonomy. The study tackled the issue from a current and historical point of view by carrying out some debates on the major regions of Europe. In the first part, regions that have evolved into separatism in Europe from time to time were discussed by focusing on the autonomous regions in Spain and the United Kingdom. In the second part, the regions in Italy were discussed, and the issues of identity, ethno-linguistic belonging, internal colonization and economic backwardness were elaborated. Finally, the establishment of the Committee of the Regions, a European Union institution, for the institutional solution of regional problems within the European Union and the criticisms faced by the Committee were evaluated. Thus, the way of ensuring the regional governance of the European Union institutions and their perspectives on regional differences were also revealed.
\end{abstract}

Keywords: European Union, Regionalism, Subsidiarity, European Regions.

\section{$\ddot{O ̈ z}$}

$\mathrm{Bu}$ çalışma uzun bir geçmişi ve mirası olan Avrupa'da bölgelere ve bölgeselcilik anlayışlarına odaklanmıştır. Avrupa Ortak Pazarı tamamlandığında bölgelerin daha bir güçlü bir şekilde Avrupa düzeyinde temsil edileceği öngörülüyordu. Gerçekten de Avrupa Birliği'ne üye olduktan sonra pek çok Avrupa ülkesi bölgelerini yerindelik ve yakınsaklık ilkeleri uyarınca yöneteceğini taahhüt etti. Fakat Katalonya gibi bazı özerk bölgeler geniş özerklik yerine bağımsızlık gibi "radikal" taleplerle ortaya çıktı. Çalışma, Avrupa'nın belli başlı bölgelerine ilişkin bazı tartışmalar yürüterek meseleyi güncel ve tarihsel olarak ele almıştır. İlk bölümde İspanya ve Birleşik Krallıktaki özerk bölgelere odaklanılarak zaman zaman ayrılıkçılığa evrilen bölgelere değinilmiş̧tir. İkinci bölümde ise ağırlıklı olarak İtalya'daki bölgeler tartışılarak kimlik, etno-linguistik aidiyet, iç sömürge olma durumu ve ekonomik geri kalmışlık meseleleri üzerinde durulmuştur. Son olarak, Avrupa Birliği Bölgeler Komitesi'nin Avrupa Birliği içinde bölgesel problemlerin kurumsal bir şekilde çözümü için kurulması ve Komite'nin maruz kaldığı eleştiriler değerlendirilmiştir. Böylece Avrupa Birliği kurumlarının bölgesel yönetişimi temin etme yolu ve bölgesel farklılıklara yönelik bakış açıları açığa çıkarılmıştır.

Anahtar Kelimeler: Avrupa Birliği, Bölgeselcilik, Yerindelik, Avrupa Bölgeleri.

*Corresponding Author / Sorumlu Yazar: ataseeven@yahoo.com 


\section{Introduction}

As the European Union [EU] intensifies its integration and enlargement processes, it has been observed that the regionalist tendencies tend to increase among member countries. The rise of regionalism within the EU can be attributed to several reasons. The earliest and main reason why regionalist movements gained momentum within relevant countries is the ethno-linguistic and cultural differences of these regions. These differences are seen in many regions within the EU such as Catalan and Basque regions in Spain, Scotland and Wales in the ex-EU member UK and Corsica in France.

Regionalism has ethno-linguistic and political dimensions, as well as being a theory of economic integration. In this study, concepts and issues that dominate political and sociological aspects such as nationalism, identity, and language will be discussed. Since not all regionalist approaches in 27 countries can be examined, regionalist movements in the relatively new member countries will not be emphasized. Rather, countries with deep-rooted regionalist movements within the EU will be discussed comparatively. As the separation of the UK from the EU is still a hot issue, the Brexit and regionalism in the UK are also within the scope of this study.

The notion of Europe of regions bears many implications for the present and future of Europe. Without the role of regions probably one cannot talk about a comprehensive European identity. Europe is a combination of many local and regional identities. The Europe of regions may not necessarily pose a threat to nation-states. However, regional differences and regional development strategies which aim to construct specific remedies for specific problems of regions keep influencing the European project. Hence, the relations between nationstates and the EU have been deeply shaped by such notions as subsidiarity and regional autonomy.

It seems that the regions of EU demand more economic and political autonomy. The factors that trigger or strengthen this demand can be examined under two basic categories and parts. The first part is the kind of internal colonialism put forward by the regions like Corsicans in France. According to this view, the development of Corsica has deliberately been blocked by the central government in Paris. In the second case, there happens to be seen Italy's Northern League. According to them, the poorer, dependent and less industrialized, less developed, yet more dominant in the national political arena, the Southern Italy has become a hobble for the Northern Italy and this is why, the North deserves more autonomy and independence in its internal affairs.

Alongside the desire for autonomy, there is also a concern that the supranational, central Brussels administration will not care about the needs and priorities of local centers. This problem was tried to be overcome by the EU's policy of subsidiarity, which stipulates that the Union's policies are to be carried out through the lowest possible administrative unit. However, the reason why regionalism is gaining strength and playing an increasingly dominant role cannot be attributed to one single, precise, simple reason. In many cases, regionalism tends to exist at varying levels within different regions.

For centuries one of the most fundamental entities of states has been their sovereignties (Özdemir, 2012, p. 380) and the positions of regions in Europe have been paving the way for disputes regarding the sovereignty of states. Also, due to the disputes concerning the external borders of Europe and the challenges its diversity present it is hard to define what Europe and European is (McCormick, 2011, p. 61). Regions lie at the heart of these disputes and discussions concerning what Europe and European are.

In this regard, this study focused on several regions of Europe, mainly the regions of Spain, Italy, France and UK. In the first chapter, the separatist movements in Spain and UK were examined. In the second chapter, the regional differences of Italy and France were tackled and a comparison regarding the regional developments of these countries was made. Further, the role of EU institutions in regional governance was discussed through an examination of the Committee of Regions. 


\subsection{The Europe of Regions}

Due to supranationalism, European integration and the strong effects of regionalism, the concept of nationstate is seriously being discussed within the EU. In a way, "giving more autonomy to smaller regions could block nationalist currents that slow down the integration process and help these small regions solve their economic and political issues within the EU context. In fact, EU regionalism has a character that rejects constitutional definitions" (Calleya, 2000, p. 27).

However, looking beyond the economic reasons for the rise of regionalism within the EU, the most obvious reason seems to be the existence of ethno-linguistic differences. This difference is probably the most fundamental feature that distinguishes one society from another. Small groups that have existed for centuries in modern democratic states and also in line with the EU's principle of subordination have the right to speak more for their own political needs and interests.

In this vein, there are some parties in Spain representing Catalan and Basque minorities that have emerged due to these ethno-linguistic differences. The two leading parties among them are the Catalan Republican Left Party and the Basque National Party. These parties can be described as ethno-lingusitic, and "such nationalist parties tend to increase their support as their decision-making bodies become more nationalistic. Convergence and the Unity Party is on a more moderate line. These parties made significant gains in the Spanish parliament in the 1977 and 1986 elections" (Scully \& Richard, 2010, p. 134).

Subsequently, the main regional parties, the Proximity and Unity Party and the Basque National Party, strongly supported Spain's accession to the EU. These two parties acted in accordance with their common interests by opposing Madrid's strong centralist policies. However, the separatism in Catalonia was sparked by a series of events, which resulted in the exile of pro-independence leader Carles Puidgemont (Ulusoy, 2020, p. 147). In fact, in the face of Madrid's harsh response, Puidgemont left the independence decision to members of parliament. Hereafter the members of parliament declared a unilateral independence. Following this decision the Madrid government abolished the Catalan parliament and issued an arrest warrant for some Catalan leaders including Puidgemont (Ulusoy, 2020, p. 147). In spite of EU membership and a relatively long democratic experience the Catalan nationalists pursue independence and deny centralism. The reforms put into practice between 1982 and 2006 in Spain and the re-definition of Spanish nation fell short to suppress the independence movements peacefully (Humlebæk \& Jiménez, 2018, p. 153). Further, the Spanish central government pointed out the Scottish independence referendum to support its thesis that with strong autonomy and rights a region can willingly coexist with a central government in a European context.

Although it is not a part the EU anymore, the UK is still an important European power and culture. So, to understand European regionalism, one also should look at regionalism in the UK. The understanding of regionalism in the UK is also fed by the identity differences of the English people and the peoples of Wales, Scotland and Ireland. The separatist movement was also effective in Northern Ireland for a long time.

Scotland, on the other hand, was far from separatist rhetoric until 2014. But in 2014, Scotland held a referendum to decide to leave or remain a part of the UK, in which the majority decided to remain. However, in the aftermath of the Brexit the Scottish nationalists demand another referendum for Scottish independence and EU membership. The Scottish Nationalist Party is the party that had strongly supported independence in the 2014 referendum. This movement, which is the strongest party in Scotland, is at the center of regionalism and demands for independence rather than autonomy (Mattelaer, 2017, p. 4). In this case, the implementation of Brexit was inevitable. From the point of view regionalism in Europe this could spark a new conflict. Nevertheless, whatever the composition of the British government, it could not have avoided the political imperative to deliver Brexit and make the best of an unknown situation. Given that the debate over immigration played such a prominent part of the Leave campaign, it is obvious that the principle of free movement of 
persons cannot be maintained in the future relationship between the UK and the EU (Mattelaer, 2017, p. 4). The emphasis on the control of immigration applies to all four autonomous regions of Britain.

In this regard, in Northern Ireland, the dusts seem to have settled. In the region where religious and cultural differences are predominant, Sinn Fein and the pro-central government Ulster United and Democratic Union parties have varying levels of influence. In Wales, the regionalist party called Plaid Cymru is struggling to protect Welsh culture and identity, even though it does not have a very sharp separatist rhetoric. It can also be said that it was partially successful in this because around a fifth of the Welsh population can speak their mother tongue today. Thus, Wales has no desire to leave the Union yet.

It is clear that economic factors along with cultural differences can trigger regionalist movements within a country. The internal colonialism criticism or approach also has an economic aspect. There are many regions that feel that they are not treated equally by the central government and therefore feel humiliated due to their underdevelopment. Corsica and Breton regions in France express their regionalist approach through this discourse. The Breton Liberation Army, which emerged in the 1960s, for example, expressed the demand for political autonomy for Breton, claiming that the Breton people were neglected by the Paris administration. They demanded from France to devote more resources to regional development and improve the economy of the region. This is an indication that the people of the region feel forgotten and neglected.

These regions have linguistic distinctness as well as economic backwardness. The regions which remain undeveloped in terms of economy compared to other regions put the blame on the center, which leads to stronger regional and nationalist movements. The model here is internal colonialism. As the disadvantaged region feels exploited, it thinks that its resources are transferred to the center, and also if this region is culturally and linguistically different, the regionalist and nationalist reaction will be stronger. Ultimately, "conflicts can be prevented by more specifically defining the region, space and community building processes with the EU core values" (Rumelili, 2007, p. 158).

The EU itself has put in place Structural funds to solve at least some of these problems. Tools such as the European Regional Development Fund, the European Social Fund, the European Agricultural Guidance Fund, and the Cohesion Fund have been created to serve this purpose. Efforts were made to compensate for the regional development gap through these funds. In this context, a partnership has been established between the EU and local governments and local authorities. Whether the objectives of the fund were achieved or not was followed up with the help of this partnership. Moreover, the Committee of Regions was established in 1994 to establish stronger links between the regions and the central Brussels administration. "Of course, this institution has been criticized because of the current crisis, unemployment and its ineffectiveness except for the Committee's advice and lobbying activities. Local governments who held big hopes for the committee were disappointed" (Scully \& Richard, 2010, p. 6).

According to the Lisbon Treaty, the Committee has the right to apply to the Court of Justice for the follow-up of the subsidiarity principle. This increased the political role and significance of the Committee of the Regions. Despite this, the Committee's decisions still have not gone beyond being advisory. In fact, even before the Committee was established, regional governments were able to open offices in Brussels (Hooghe \& Marks, 1996, p. 83).

\subsection{Identity, Margins, New City States}

If we look at other major political regions within the EU countries, one of the locations where regional differences have serious political effects is the Northern regions of Italy. Regions such as Lombardi where Milan is located are more industrialized, richer and less influenced by organized crime organizations compared to Southern Italy. Because of this, Northerners feel that the backward Southern and corrupt central Roman governments stall their efforts to become richer. This brought about the emergence of various factions which have demands ranging from more autonomy to full independence. 
Lombardi, Venice, Piedmont, Emilia, Romagna, Liguria, Tuscany and Friuli regions were gathered under a single party roof. The Northern League was founded in 1991 under the leadership of Umberto Bossi, who previously ran the Lombard League. The Southern economy, which received a large amount of government support, could not recover (Agnew, 1995, p. 156). Infrastructure investments and industrialization efforts did not yield results. In addition, the Southerners benefited more from the recruitment of the state, which started to offend the Northerners. These disappointments started to be expressed strongly by the Northern League.

During the Berlusconi period, important ministries were given to the MPs from the Northern League. In 2009, a system that could be called tax federalism was passed by the representatives of the Northern League. In 2012, the founder of the League, Umberto Bossi, left his post. The basic philosophy of the movement can be defined as political federalism, tax federalism and regionalism. This movement can contribute to EU regionalism by filing away excessive ideas within the framework of the EU's multi-layered governance understanding (Gualini, 2004, p. 225). Following the ideas of Bossi Matteo Salvini first became the leader of the Lega and then became minister of internal affairs for a while and now the Lega stresses the irregular immigration issue rather than the backwardness and underdevelopment of the South (Gualini, 2004, p. 225).

Similar examples resonating the Italian regions can be found in regions of Spain, discussed above. Catalonia, Galicia, Euskadi (Basque Country) and Andalusia can all be considered relatively successful in terms of economic development and growth. These four regions benefit seriously from the autonomy existing in Spain. The reason why these regions demand self-governance and more strong participation in decision-making mechanisms is that they are relatively rich regions in terms of economic indicators.

Apart from the ethno-linguistic difference and economic problems, which are the driving force of the growing regionalism, there is a suspicion that the Brussels central administration, which operates with a supranational administration model, will not be able to meet the needs of many large and small regions within the EU. The EU tries to overcome these with principles such as subsidiarity and subordination, which stipulate that the Union's policies are carried out by the lowest possible administrative units. Although it may seem like a paradoxical relationship at first, regionalism and supranational centralism cooperate in weakening national centralist understandings and reducing the influence of national governments. In fact, some of the doubts of the regional governments have been justified.

How can regional governments rely on a supranational government when they cannot rely even on their national governments to pursue their aspirations and interests? How long will the Committee of the Regions serve this purpose? Already, EU regions have started to criticize this committee (Syssner, 2006, p.38). Almost everyone in the EU agrees that regional development should be done from the bottom, not with government aid or private funding to peripheral locations, but rather from the bottom up, with the dynamics of the region itself (Syssner, 2006, p. 38). Therefore, the Committee of the Regions is expected to bring forward the problems of the EU regions more often.

Restricting centralization at the state level can weaken nationalism and strengthen integration within the nation. But if the EU integration triggers economic problems, on the contrary, in this case, nationalist and unitary movements may get stronger and cause internal conflicts. The rallying of right-populist parties both in national elections and in the EU Parliamentary elections may mean an increase in regional conflicts. To prevent this trouble, the EU institutions should bring the decision-making processes for Europe closer to ordinary citizens (Loughlin, 2001, p. 26).

There are already strong autonomous regions within the EU, but the Catalan region, Scotland and the Basque regions seriously put forward independence beyond autonomy. The regionalist and separatist movements in these regions, which believe that the center will not contribute to the economic development of the region and stall the self-governance of those regions, indicate that center-region / periphery conflicts will take place in the EU for a longer time than anticipated. 
Implementing the EU policies through the lowest possible administrative unit lies in meeting the demands and needs of many regions within the EU. The concept of nation-state in the EU is being eroded by regionalist powers and EU integration, but the economic failures and the central Brussels administration's awkward governance and its occasional indifference to the needs of the regions for the benefit of the nation-state structures such as France might mean that the Regions of Europe will face difficulties.

As can be seen, there are various factors that lead to the strengthening of regionalism within the EU member states. These factors include demands for autonomy, the strengthening of existing autonomies or the independence demands of already autonomous regions. These demands are manifested primarily in the ethnolinguistic difference, the feature that distinguishes one region from another in its simplest form. This kind of ethno-linguistic regionalism is found in regions such as Catalonia, Basque, Andalusia, Breton, Corsica, Scotland and Flanders. However, another demand for political and economic autonomy or independence lies in the sharp regional differences within nations.

The emergence of regional movements leads the discussion to two main points. The first is that a region's demand for political and economic autonomy or independence stem from the fact that a region feels to have been exploited by the central government and sees itself as a kind of internal colony. The second point is that a region thinks that its economic potential is strong, that its region is more advanced than the rest of the country, and that the central government is a serious obstacle to realizing its potential and its development can only be achieved through a strong autonomy. The first situation is seen in Corsica and Breton regions of France, in regions such as Northern Ireland and Scotland and Flanders.

The second issue is an argument and discourse carried out by regions such as Catalonia, Galicia and the North of Italy who want to have more say on the money they earn and tax they collect because their economies in general are stronger than the other regions of their countries. In addition, concerns that a supranational central government based in Brussels would not be responsive to regional problems led the Union to adopt the principle of subsidiarity. Accordingly, the lowest possible administrative unit was made responsible for the implementation of EU policies. This principle is also effective in weakening centralization, strong national governments and nationalism.

The result of giving more importance to regional movements is the acceleration of European integration. From the weakening of central governments and nation-states benefits both regionalists and European integrationists, and their interests overlap. Thus, granting greater autonomy to smaller regions facilitates European integration and becomes effective in meeting the needs of regions within the EU.

Furthermore, it can be concluded that there are two different trends within the EU countries other than the regional approaches mentioned above. These trends can roughly be described as euro regionalism, a form of supranational regionalism, and nation-state regionalism. EU regionalism also has an attitude that is reminiscent of the old European city-states and that draws inspiration from these city-states (Jönsson et al., 2003, p. 132). Decentralized city-states can also contribute to national development by preserving the diversity of regions. In the formation of the regionalism of the EU, on the basis of this historical perspective, a bottom-up management model has been made effective by "bringing together the political and economic mind" (Jones \& Keating, 2001, p. 171).

The revival of extremist movements which assert that in the EU integration process the peoples of Europe are not actors but subjects and a kind of expert authority direct the course of EU is closely related to the regional issues. It is the search for a new European identity that pushes peoples to question their national, regional and local identities. Although the European integration process has been continuing more than fifty years, we cannot talk about a collective European identity yet (Karlsson, 2007, p. 80). As an economic entity the Union is a reality but in terms of cultural and identity values it is far from being a union. 
The idea of Europe, a new narrative for Europe, and unity in diversity may sound a romantic historization of Europe (Cederberg, 2017, p. 39) but for regions of Europe this ideal and romantic historization may play a role in restructuring the idea of Europe. The city states of ancient Europe, the Renaissance city states and brand mark cities of modern Europe, all provide relief for stronger regions. Being in a region also means being in a margin. To combine unity and diversity, to resolve the tensions between universal and particular values are challenges Europe face. In fact as Jacques Rupnik puts it: "There are historically different ways of belonging to Europe and although the center of Europe might be difficult to identify, it has several peripheries" (Ifversen, 2019, p. 27).

The EU is a model under pressure, its approach to regions and regionalism is also under the influence of this pressure:

Recent crises in the European Union have tainted outsiders' perceptions of it as a model of specific policy regimes; yet, the most fundamental problem has crystallised in Brexit, which expresses principled opposition to the very idea of regional cooperation. Nevertheless, the notion that regional cooperation can help nation states to secure peace and enhance economic prosperity continues to be most prominently embodied by the European Union - remaining an attractive one in a world in which conflict and poverty are still pervasive (Lenz, 2018, p. 1).

The EU process is a complicated and dynamic process and as it happens in almost all dynamic process fears and anxieties emerge too. In some cases these fears and anxieties may outweigh opportunities (Çelebi, 2002, p. 115). The same thing applies to regionalist approaches for the EU. Regionalist views are parts of dynamic processes that shape the architecture of the EU and its institutions.

\section{Conclusion}

This study tackled the regions of Europe by comparing several regions in Europe in terms of their ethnolinguistic differences, economic structures and identities. The governance system of EU and its impact on the regional developments were analyzed. Throughout the integration process European regions gradually have asserted their agenda on the European level. However, the demand for independence has been perceived as an action that pushes the limit of European tolerance on the autonomy of regions.

Step by step, today multilevel governance and Europeanisation have given regions a key role in understanding the complex and fragmented system of European politics. In this sense, this article has illustrated how Europeanization reinforces multilevel dynamics of regions. However, the article also reveals how fragile the balance between the center-region relations is and to what extent Europeanization arbitrates the conflicts.

The future role of the regions in the process of European integration in the aftermath of Brexit, whether the regions influence the multilevel governance and the significance of sub-national actors through a historical perspective were discussed. Constructing Europe from bottom, instead of a top-down approach, which marked the foundation of European project, is the demand of peoples of Europe. The implementation of principle of subsidiarity, empowerment of regional parliaments and brandization of cities resonate a comeback to city states of antiquity. The Europe can deepen its integration through rebranding of regions and cities as cultural, economic and political centers.

This study predominantly discussed the regions in UK, France, Italy and Spain. In discussing these regions, the concepts of margin, periphery, center, identity and governance become conspicuous. Therefore, one way to conceptualize Europe is to lay stress on its regional differences and diversity, on its universality in particularity. Europe is not solely made of nation-states. Nor does it belong to a single structure deciding for all peoples of Europe. Historical lines, the legacy of city states generate a convergence among European regions as well as generating tensions between regions and centers. 


\section{References}

Agnew, J. (1995). The rhetoric of regionalism: the Northern League in Italian politics, 1983-94. Transactions of the Institute of British Geographers, New Series, 20(2), 156-172. https://doi.org/10.2307/622429.

Calleya, S. C. (2000). Regionalism in the post-Cold War world. Ashgate Publishing.

Cederberg, C. (2017). Europe as identity and ideal: reading Barroso's 'new narrative' heretically alongside Hegel, Husserl and Patočka. In J. Fornäs (Ed.). Europe faces Europe: narratives from its Eastern half (pp.35-61). Intellect.

Çelebi, A. (2002). Avrupa: Halkların siyasal birliği. Metis Yayıncılık.

Gualini, E. (2004). Multi-level governance and institutional change: The Europeanization of regional policy in Italy. Ashgate Publishing.

Hooghe, L., \& Marks, G. (1996). "Europe with the regions": Channels of representation in the European Union. Publius: The Journal of Federalism, 26(1), 73-91. https://doi.org/10.1093/oxfordjournals.pubjof.a029841

Humlebæk, C., \& Jiménez, A. M. R. (2018). La nación en España: un instrumento de medida cualitativo para una cuestión compleja. Revista Española de Investigaciones Sociológicas, 161, 141-155. http://dx.doi.org/10.5477/cis/reis.161.141.

Ifversen, J. (2019). Europe and the concept of margin. In T. Hauswedell, A. Körner, \& U. Tiedau (Eds.), Re-mapping centre and periphery: Asymmetrical encounters in European and global contexts (pp. 27-43). UCL Press.

Jones, B., \& Keating, M. (2003). The European Union and the regions. Oxford Scholarship Online.

Jönsson C., Tägil S., \& Törnqvist, G. (2003). Organizing European space. Sage Publications.

Karlsson, I. (2007). Bölgeler Avrupası. (T. Kayaoğlu, Trans.). İstanbul Bilgi Üniversitesi Yayınları.

Lenz, T. (2018). The European Union: A model under pressure. German Institute of Global and Area Studies (GIGA).

Loughlin, J. (2001). Subnational democracy in the European Union: Challenges and opportunities. Oxford University Press.

Mattelaer, A. (2017). Towards a Belgian position on Brexit: Actively reconciling national and European interests. Egmont Institute.

McCormick, J. (2011). Avrupa Birliğini anlamak. (Y. Şahin \& H. H. Şahin, Trasn.). BigBang Yayınları.

Özdemir, H. (2012). Avrupa mantı̆̆ı: Avrupa bütünleşmesinin teori ve dinamikleri. Boğaziçi Üniversitesi Yayınevi.

Rumelili, B. (2007). Constructing regional community and order in Europe and Southeast Asia. Palgrave Macmillan.

Scully, R., \& Richard J. W. (2010). Europe, regions and European regionalism. Palgrave Macmillan.

Syssner, J. (2006). What kind of regionalism? Regionalism and region building in Northern European peripheries. Peter Lang.

Ulusoy, K. (2020). Katalanlar: Avrupa'da ayrılıkçılık. Ayrıntı Yayınları. 